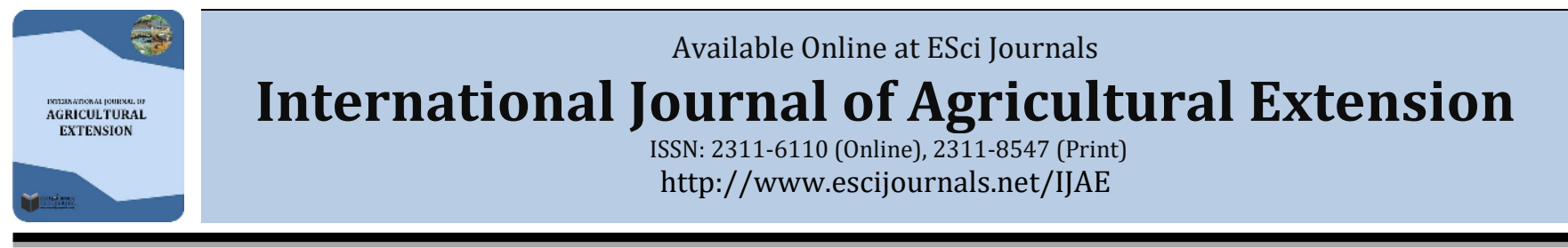

\title{
QUANTITATIVE FRAMEWORK FOR COFFEE LEAF RUST (Hemileia vastatrix), PRODUCTION AND FUTURES
}

\author{
Laura H. Kahn \\ Indiana University, School of Informatics, Computing and Engineering.
}

\section{A B S T R A C T}

The livelihood of at least 120 million people worldwide depends on the coffee supply chain. Coffee rust is among the main diseases that attacks the coffee plant and is caused by the Hemileia vastatrix fungus at temperatures between 10 - $30^{\circ} \mathrm{C}$. Coffee rust infestation leads to production losses of over $\$ 1$ billion annually worldwide. Coffee is the second largest traded commodity worldwide, with about $\$ 100$ billion in volume traded annually. Understanding if there is a relationship between Temperature, Rainfall, Rust, Production and Futures coffee rust variables is important. This research offers the first known quantitative framework for describing and visualizing the correlation between coffee rust, amount of coffee produced and futures prices.

Keywords: Commodity futures, coffee trading, data visualization, econometrics, hemileia vastatrix, pricing, statistical analysis.

\section{INTRODUCTION}

Sixty percent of total coffee bean production worldwide is of the arábica cultivar (United States Department of Agriculture Foreign Agricultural Service December 2018- Coffee: World Markets and Trade). In 2017, coffee had an estimated $\$ 70$ billion retail value in the U.S. alone. Coffee production is an essential part of the economy of over 60 countries and is the primary income source for over 100 million people (International Coffee Organization 2016). According to the UN Food and Agriculture Organization in 2016, Brazil, Vietnam, Colombia and Indonesia were the top four coffee producing countries in 2018 (Economics of Coffee, 2018).

Table 1. Food and Agriculture Organization Coffee Production Statistics, 2016.

\begin{tabular}{lc}
\hline Country & Coffee Production (Arábica and Robusta cultivars in tonnes) \\
\hline Brasil & $3,019,051$ \\
Vietnam & $1,460,800$ \\
Colombia & $745,084^{*}$ (data based on imputation methodology) \\
Indonesia & 639,305 \\
Worldwide & $9,335,874$ \\
\hline
\end{tabular}

Brasil, Colombia and New Caledonia produce 32.34\%, $7.98 \%$ and less than $0.01 \%$ of the world's coffee supply respectively (FAO). The growing regions of all three countries have similar climates and grow the arábica cultivar. Vietnam and Indonesia produce coffee of the robusta variety, which is outside the scope of this * Corresponding Author:

Email: laurakahn2@gmail.com

(C) 2019 ESci Journals Publishing. All rights reserved. research. Data illustrated in the Figure 1 shows Brasil's top four coffee growing regions of Minas Gerais, Espírito Santo, Bahia and São Paulo. Coffee exports account for about $50 \%$ of all Brasil's agricultural exports. Additionally, in 2008 about 3.5 million people of the total population of 191.5 million were involved in the coffee industry (Souza, 2008).

Figure 2 shows Colombia's major coffee growing regions of Caldas, Risaralda, Quindío and Valle del Cauca (Coffee 
production in Colombia). Coffee exports account for about $31 \%$ of all agricultural exports.

According to the Ministry of Agriculture and Rural

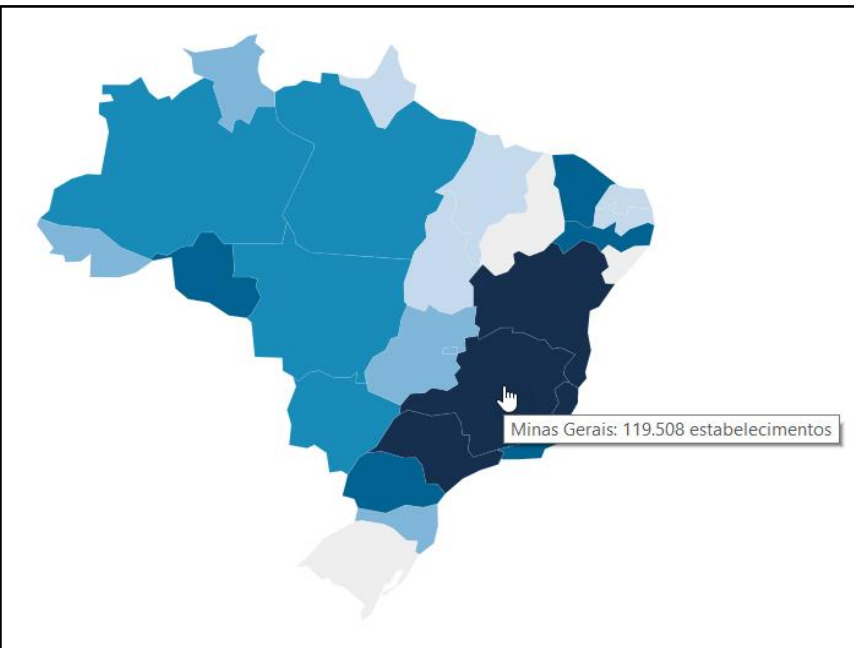

Figure 1. Brasil's coffee growing regions.
Development, coffee growing generates about 800,000 direct jobs and 1.6 million indirect jobs. (Colombian Coffee Insider).

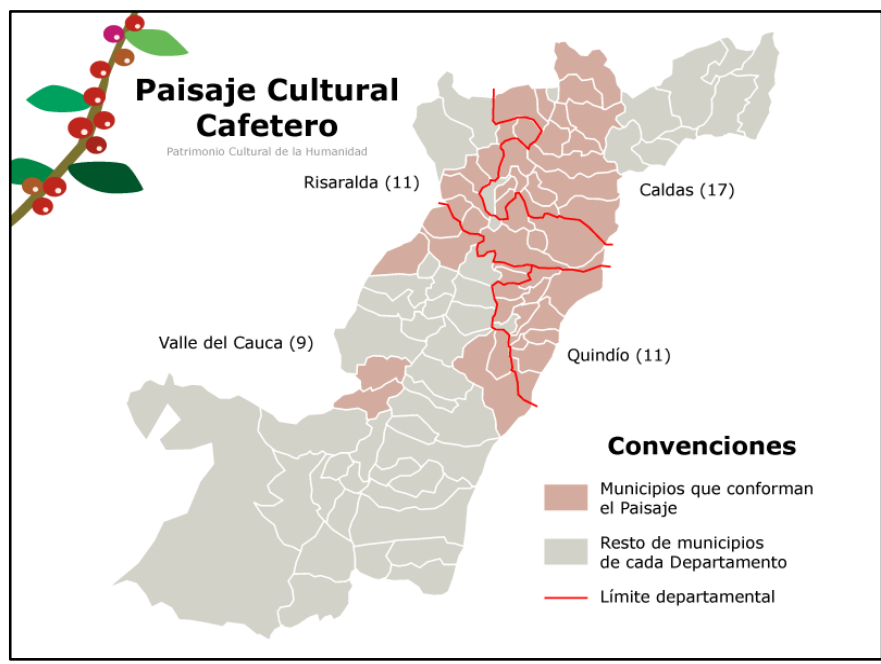

Figure 2. Coffee Growing Regions of Colombia.

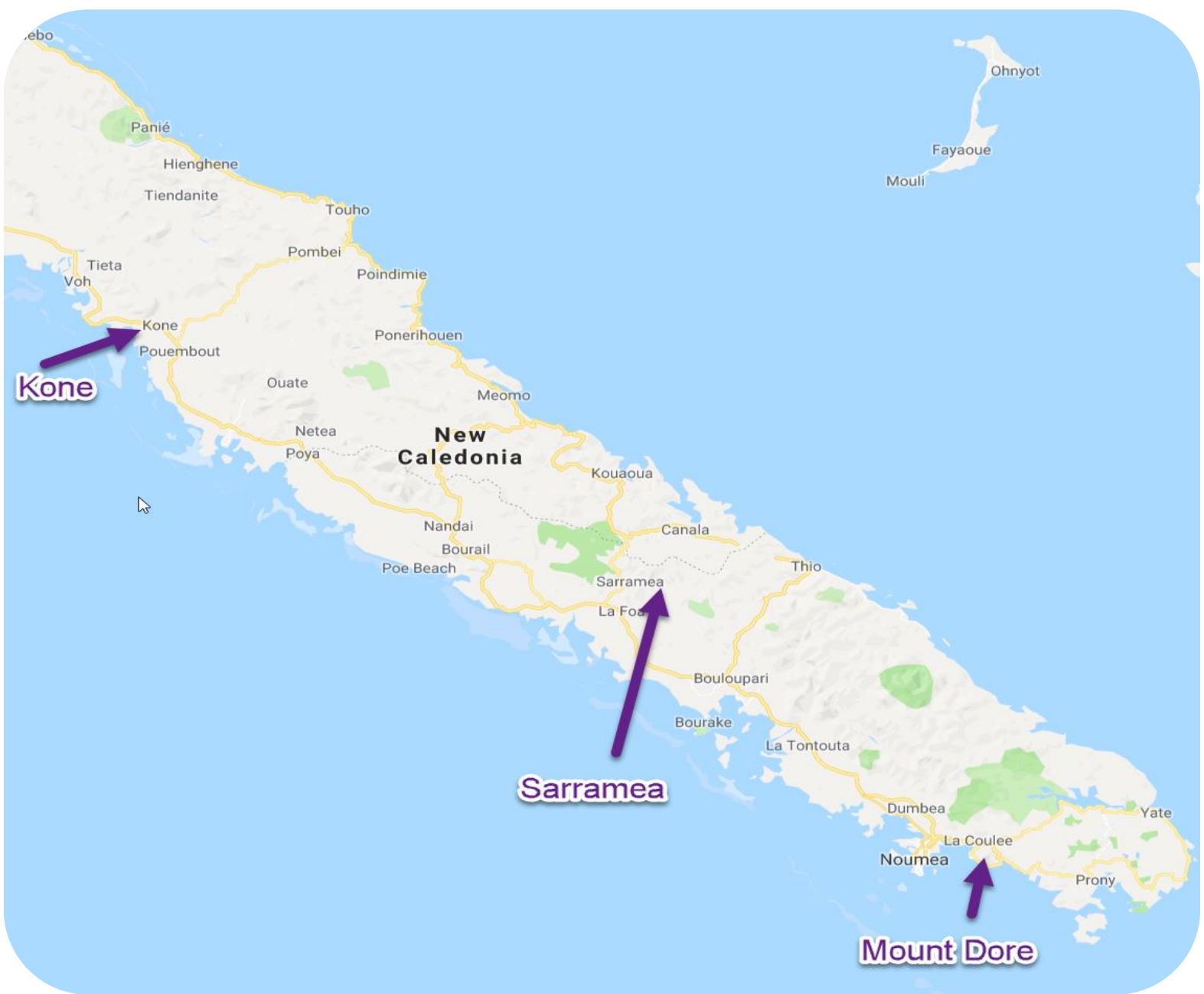

Figure 3. New Caledonia's coffee growing regions of Mount Dore, Kone and Sarraméa. 
Coffee leaf Rust is caused by the Hemileia vastatrix fungus at temperatures between $10-30{ }^{\circ} \mathrm{C}$. Signs of Coffee Rust appears as yellow-orange powder on the underside of leaves as shown in figure 4 . This fungus has spread to all coffee cultivation areas worldwide (Hemilia Vastatrix). Coffee Rust leads to production losses of approximately $\$ 1-2$ billion annually worldwide and may affect futures prices (McCook). Understanding if there is the relationship between Temperature, Rainfall, Rust, Production quantities and Futures prices is important to anyone affected by the coffee supply chain and commodities market.

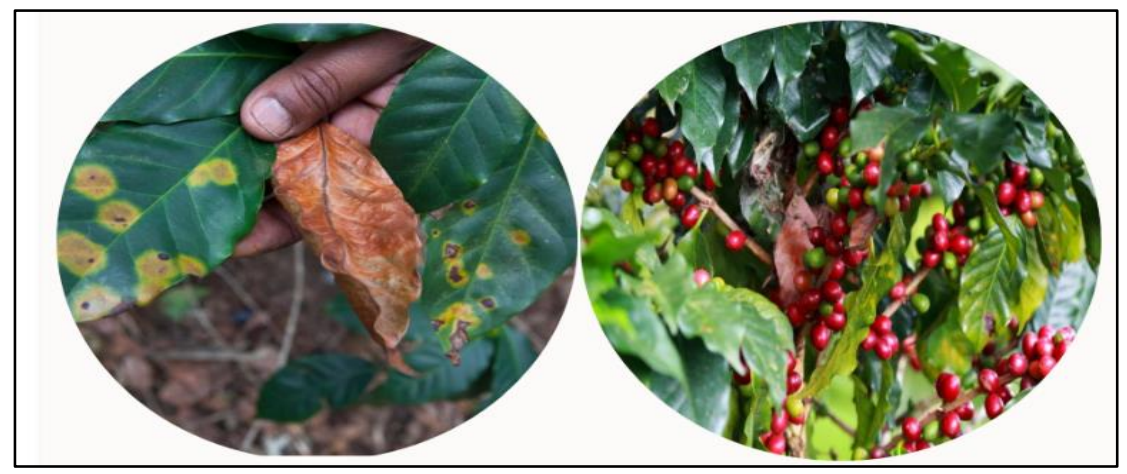

Figure 4. Coffee rust.

Coffee futures are standardized, exchange-traded contracts in which the contract buyer agrees to take delivery, from the seller, a specific quantity of coffee beans (arábica variety) at a predetermined price on a future delivery date. Coffee futures are traded on average 252 days per year on the U.S. New York Stock Exchange (NYSE) from 0930-1330 daily (Coffee C Futures). To date research has been done that shows anecdotal links between weather conditions such as rain, temperature, humidity and coffee rust (Avelino, 2015). The study will establish a quantitative framework for the relationship between Temperature, Rainfall, Rust, Production and Futures. This research makes an important contribution to agricultural, economic and financial sectors that are affected by coffee.

The hypotheses are;

- Rain, Temperature, Production, Rust and Futures are correlated to each other.

- More rain increases rust.

- Higher temperatures increase rust.

- More rust decreases production.

- Less production increases futures.

- More rust decreases futures.

Literature Review: A qualitative link between average rainfalls, minimum and maximum temperatures, shade amount, and rust is described by Avelino (2006). Luaces (2011) describes using fruit load, plant spacing, and weather scores to predict when coffee rust will occur from October 1998 to October 2006 in Varginha Brasil.
Jaramillo suggests a qualitative link between coffee leaf rust, lower coffee production and increase futures. Avelino (2015) also suggests a possible link between coffee rust and prices in general but does not discuss futures prices. Yap (2017) explores the effect of precipitation, exchange rate and import volume on Brazilian coffee futures prices. Lamouroux (1995) describes qualitative relationships between soil $\mathrm{pH}$, soil structure and temperature between coffee plots influence the amount of coffee rust in New Calcedonia. McCook uses artificial intelligence machine learning models to predict 27 futures prices based on daily historical prices data but does not describe relationships with production or weather features. None of the existing research visualizes the relationship between coffee rust, production and futures.

\section{METHODOLOGY}

Data Collection Ethics: Since the data was about weather conditions, plants, production amounts and futures prices, there are fewer ethical implications during the data collection process. The data collection impedes no one's privacy since human subjects were not involved. Systems and processes used were not biased against any groups of people. Since the data is open on the web and not under a license or proprietary in any way, the data is not considered private. The data also does not contain any personal identifiable information so the reuse of the data for research purposes does not violate any ethical principles. Also since this project did 
not require additional studies since existing data was used, no permissions were required.

Data Acquisition: The data set includes 323 observation of four input variables: average Rain ( $\mathrm{mm}$ ), average Temperature $\left({ }^{\circ} \mathrm{C}\right.$ ), Rust (percent disease that covers the plant), Production (measured in 1000-60 kg bags of coffee beans) and one output variable: Futures (in US dollars). Weather and physical crop properties that affect rust were included to make the simplest and easiest to interpret model possible. The literature suggests that two main physical crop variables determine coffee rust - air temperature and rainfall amounts (Yap, Jaramillo, Avelino 2006). The literature also suggests that farmers apply rust control measures such as pesticides when crop leaves have $5-20 \%$ diseased spots (Cunha). Certain crop management variables such as fertilization and pesticide use were not included to avoid introducing confounding variables into the analysis. Furthermore, it was assumed that adding these crop management variables would not add a significant amount of value to quantifying the relationships between variables and the hypotheses. Other attributes such as soil humidity, $\mathrm{pH}$, shade amount and day length may be significant variables that affect rust but were not included in the analysis since there was no consistent and reliable source data for Brasil, Colombia and New Caledonia. The effects of these other weather variables were not considered in the rust analysis.

\section{Country Level Data}

Brasil: The rust monthly data from September 2005August 2006 was calculated from the Varginha region as described by Meira Figure 2, "Lavoura Larga-Carga Baixa". The rust daily data from September 1, 2008September 11, 2008 and September 1, 2009-September 11, 2009 was exact as shown in Paulo Figure 1.

The 80 additional observations from September 2008December 2009 were assumed to be missing completely at random and calculated using the k-Nearest Neighbor imputation method described by Beretta.

Average monthly country rainfall and temperature were obtained from the World Bank Climate Change
Knowledge Portal. Rust, Temperature and rainfall weekly data from September 6, 2008- September 11, 2009 was extracted from Adamantina region as described by Paulo Table 1 .

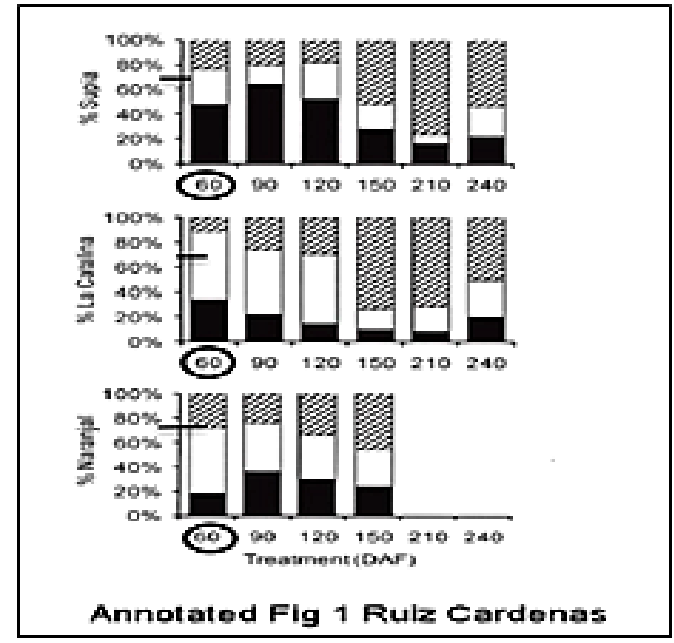

Figure 5. Annotated figure 1 of Coffee Borer in Colombia from Ruiz-Cárdenas.

Colombia: For Colombia, the rust data from January December 1995 was calculated by the following method as shown in Figure 5. The presence of coffee borers on the plants were assumed to be the same as the percent rust. Even though coffee borers attack the stem and rust attacks the leaves, the result of disease and damage to the plant is overall the same. Sixty days after flowering was assumed to be the closest measurement to the beginning of the growing cycle. The black bars in Figure 5 are percent dead, the white bars are percent leaves that have disappeared. The percent rust is equal to 100 minus the sum of percent dead and percent disappeared as shown in Table 2 . This calculated rust amount was used for each weekly observation in the 1995 Colombian dataset. Production data (crop year is April-April) is obtained from the International Coffee Organization. Figures data is obtained from Coffee "C" Futures Intercontinental Exchange Stataistics (Commodity Future Price Quotes for Coffee).

Table 2. 1995 Colombia Rust Calculations.

\begin{tabular}{lc}
\hline Region & Rust Calculation \\
\hline Naranjal & $100-(50+25)=25 \%$ \\
La Catalina & $100-(30+60)=10 \%$ \\
Supia & $100-(20+55)=25$ \\
AVERAGE & $20 \%$ \\
\hline
\end{tabular}


Table 3. Preprocessed Colombian dataset from Corrales.

\begin{tabular}{cccc}
\hline Lot & Pesticide Applied & Rust $\%$ & Date of Rust \\
\hline 1 & No & 3.85 & Aug-11 \\
2 & No & 3.37 & Aug-11 \\
3 & No & 1.09 & Aug-11 \\
4 & No & 3.63 & Aug-11 \\
\hline
\end{tabular}

For Colombia the monthly rust data from August 2011March 2013 was from supplemental data provided by David Camilo Corrales Munoz in August 2017 and can be found in the Supplemental Data section. After the document was translated from Spanish to English with an online translator, all columns were removed from the original dataset except "Lote" (lot where coffee was planted), "Control royo mes anterior" (pesticide applied the previous month), "Tasa de infección" (Rate of coffee rust infection) and "Fecha Infección" (Date of Rust). Plants that had no pesticides applied the previous month were used. The number of observations for each month varied from 1-21 observations. A snippet of the preprocessed dataset with the remaining columns from Corrales is shown in Table 3.

The individual land plots rust percent for each month were averaged and the average value was used for all weeks within each month. Missing monthly data from various months (40 observations) were assumed to be missing completely at random and calculated using the kNN imputation method (Beretta).

Production data (crop year is April - April) is obtained from the International Coffee Organization. Futures data is obtained from Coffee "C" Futures Intercontinental Exchange statistics ("Commodity Futures Price Quotes for Coffee).

New Caledonia: For New Caledonia from March 1989 October 1991, the rust data are from Yate and Canala plots (lowlands regions) in Table 1 of Lamouroux. An average was taken for two Yate plots and two Canala plots. The same rust amount is used for all months within this time period since no more granular data is available.

Production data is obtained from the International Coffee Organization. The same monthly value is used for all months and is calculated by dividing the total yearly production by 12. Futures data is obtained from Coffee "C" Futures Intercontinental Exchange statistics (Commodity Futures Price Quotes for Coffee).

Additional data points were added to the original dataset to include weekly observations within each time period for each country.

Data Assumptions: Rainfall, Temperature, Rust and Production values were used for each date within the same month. The Rust variable for Brasil, Colombia and New Caledonia is calculated as described in Section A. Rainfall, Temperature and Futures variables are exact measurements. Rainfall, Temperature and Rust are reported monthly. Production is only reported annually by country so monthly amounts were calculated by dividing the yearly amount by 12 . None of the input variables (Rainfall, Temperature and Rust) are reported bi-weekly. Only the Futures variable is available daily. Coffee futures are reported worldwide not by country on the U.S. NYSE. There is no other known freely available persistent data at a country-level for futures prices. Temperature and rainfall are similar for Brasil, Columbia and New Caledonia which means similar growing conditions so combining data from these three coffeegrowing regions for our framework is acceptable. The impact of climate change on coffee growing regions has been studied by (Avelino 2006) and many others. However, any possible implications of climate change on the Rust, Production or Futures was not included in the analysis. All data was available publicly and was assumed to be accurate and trustworthy.

Data Limitations: Since Vietnam and Indonesia do not produce the arábica variety of coffee, the lack of data from these countries is outside the scope of this research.

Since Brazil and Colombia are in the top five coffee producers worldwide and they along with New Caledonia produce $40 \%$ of the arábica coffee, the data is considered a reasonable sample of the major coffeeproducing regions.

Futures price data from 1991-2012 was extracted from the U.S. Commodities Futures Trading Commission was located (Commodity Futures Price Quotes for Coffee.) All documents regarding coffee rust occurrences in Brazil were in Portuguese and Colombia were in Spanish 
so Google Translate was used as the best open source approximation to translate the relevant figures and data. Data Preparation: Data cleansing is an important preprocessing step of the data acquisition process though for the research minimal processing data was enough. The 'Date' variable was standardized as MM/DD/YY format. The remaining numerical variables were standardized to two decimal places. Python 3.6 with the Pandas v0.23.4 library was used to manipulate and explore the dataset. Table 4 shows a reflection of the first five rows of the pre-processed dataset in CSV format.

Table 4. Pre-Processed final dataset

\begin{tabular}{lccccccc}
\hline & Date & Country & Rainfall & Temperature & Rust & Production & Futures \\
\hline 0 & $3 / 15 / 1989$ & New Caledonia & 352.42 & 25.28 & 6.33 & 97.92 & 23.18 \\
1 & $3 / 31 / 1989$ & New Caledonia & 352.42 & 25.28 & 6.33 & 97.92 & 23.89 \\
2 & $4 / 14 / 1989$ & New Caledonia & 309.50 & 25.35 & 15.67 & 97.92 & 26.27 \\
3 & $4 / 28 / 1989$ & New Caledonia & 309.50 & 25.35 & 15.67 & 97.92 & 25.60 \\
4 & $5 / 15 / 1989$ & New Caledonia & 252.75 & 25.32 & 23.33 & 97.92 & 22.85 \\
\hline
\end{tabular}

Table 5. Summary statistics.

\begin{tabular}{lcccccc}
\hline & Unnamed: 0 & Rainfall & Temperature & Rust & Production & Futures \\
\hline Count & 323.000000 & 323.000000 & 323.000000 & 323.000000 & 323.000000 & 323.000000 \\
Mean & 161.000000 & 189.918111 & 25.153560 & 13.762908 & 1649.058916 & 91.100217 \\
Std & 93.386294 & 92.658214 & 0.815875 & 11.107253 & 1240.730643 & 45.488614 \\
Min & 0.000000 & 1.800000 & 23.470000 & 0.000000 & 80.330000 & 21.980000 \\
$28 \%$ & 80.500000 & 117.400000 & 24.560000 & 5.000000 & 1010.330000 & 39.035000 \\
$50 \%$ & 161.00000 & 190.160000 & 25.050000 & 12.410000 & 1073.170000 & 103.830000 \\
$75 \%$ & 241.50000 & 257.360000 & 25.780000 & 20.000000 & 2783.330000 & 129.580000 \\
Max & 322.00000 & 407.700000 & 27.160000 & 50.000000 & 3832.670000 & 175.180000 \\
\hline
\end{tabular}

Exploratory Analysis: Exploratory data analysis begins by looking at summary statistics of the data. There are 323 observations from various years in Brasil, Colombia and New Caledonia. Precipitation ranges from 1.8 - 407.7 mm per month with a mean of $189.92 \mathrm{~mm}$. Temperature ranges from $23.47-27.16^{\circ} \mathrm{C}$ with a mean of $25.15^{\circ} \mathrm{C}$. Rust ranges from $0-50 \%$ with a mean of $13.76 \%$. Production ranges from 80.33 - 3832.67 (1000-60 kg bags of beans) with a mean of 1649.06 (1000-60 kg bags of beans). Futures range from 21.98-175.18 USD with a mean of 91.1 USD. The summary statistics are shown in Table 5.

\section{RESULTS}

Following a discussion of data acquisition, cleaning and processing, this section will describe the results. Visual representation of data can help answer questions posed in the original hypotheses.

The next step in the data exploration process was creating a plot of all the variables (Rain, Temp, Rust, Production and Futures) with a logarithmic scale as shown in Figure 8. A log scale was chosen since the regular scale line plot wasn't very helpful to gain any insights due to the large range of values. The y-axis was changed to a logarithmic scale to see if any patterns could be detected in the data. A few possible conclusions can be drawn from this plot: Rain might be correlated to Rust and Futures; and Temperature does not appear to change a lot so it might not be a relevant variable. The plot is still very difficult to read since it has too many variables on one chart. However, this visualization alone cannot be used to draw definite conclusions about possible relationships between variables. 


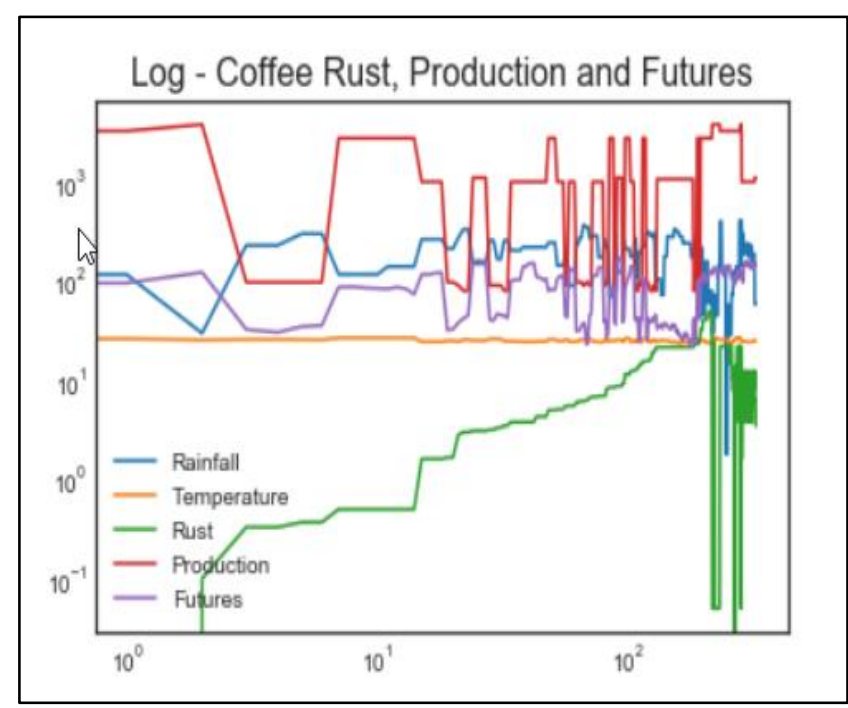

Figure 8. Logarithmic plot of Rainfall, Temperature, Rust, Production and Futures.

Next, a time-series plot of Coffee Futures was created as shown in Figure 9.

The color brown with hexadecimal value \#ac7339 was used for visually encoding the futures variable. The futures vary quite sporadically over time and there is a strange drop in prices between 120-150 days. Going back to the original data shows that futures minimum at $\$ 21.98$ in 1995. This graph confirms anecdotal comments from financial experts that Futures prices are volatile (Yap, 2015). A line plot of Rust versus Production was created to quantify and visualize the relationship between the variables as shown in Figure 10. The Production variable was plotted in black while the Rust variable was plotted with a brown color (\#663300) to help the user distinguish between the two plots. The scales of the variables are so different from one another (Production from 80.33-3832.67 1000-60 $\mathrm{kg}$ bags of beans and Rust from 0-50\%) that any meaningful relationships are difficult to see in this

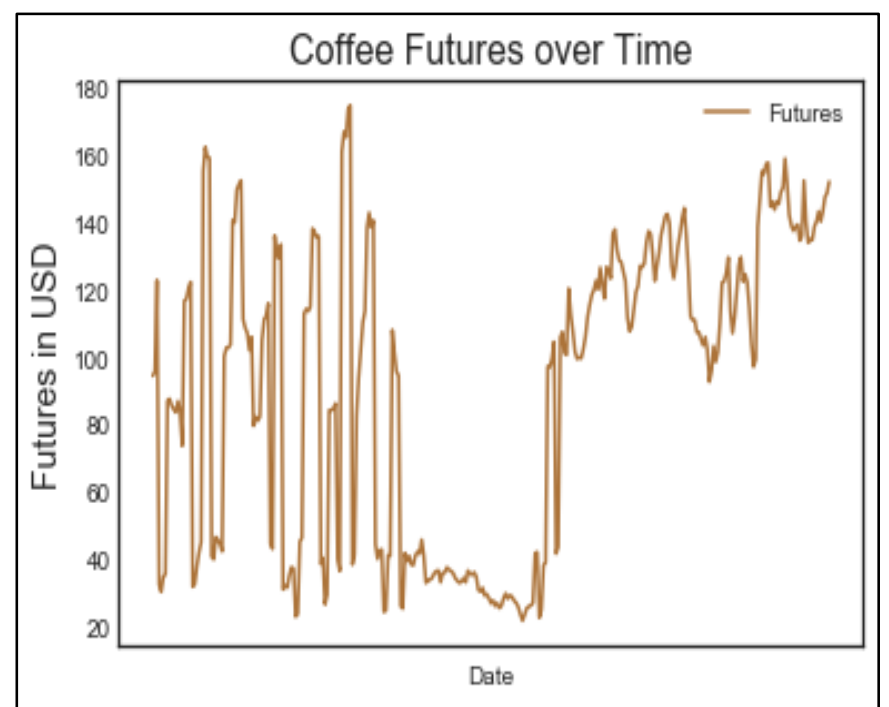

Figure 9. Time series plot of coffee futures over time

visualization. A line plot of Production versus Futures was created to quantify and visualize the relationship between the variables as shown in Figure 11. The Production variable was plotted in black while the Futures variable was plotted with a brown color (\#663300) to help the user distinguish between the two plots. The scales of the variables are so different from one another (Production from 0-3832.67 1000-60 kg bags of coffee beans and Rust from $0-50 \%$ ) that any meaningful relationships are difficult to see in this visualization.

A line plot of Rust versus Futures was created to quantify and visualize the relationship between the variables as shown in Figure 12. There may be a positive correlation between the variables. Since the scale of the variables are so different from one another (Production from 0-3832.67 $1000-60 \mathrm{~kg}$ bags and Futures from 21.98-175.18 USD) that's difficult to make any definite conclusions. 


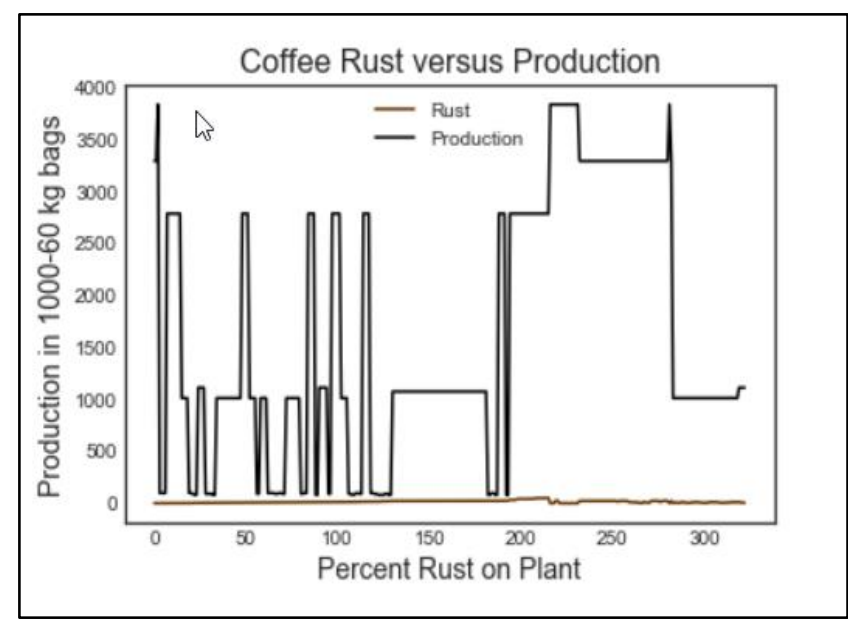

Figure 10. Line Plot of Coffee Rust versus Production.

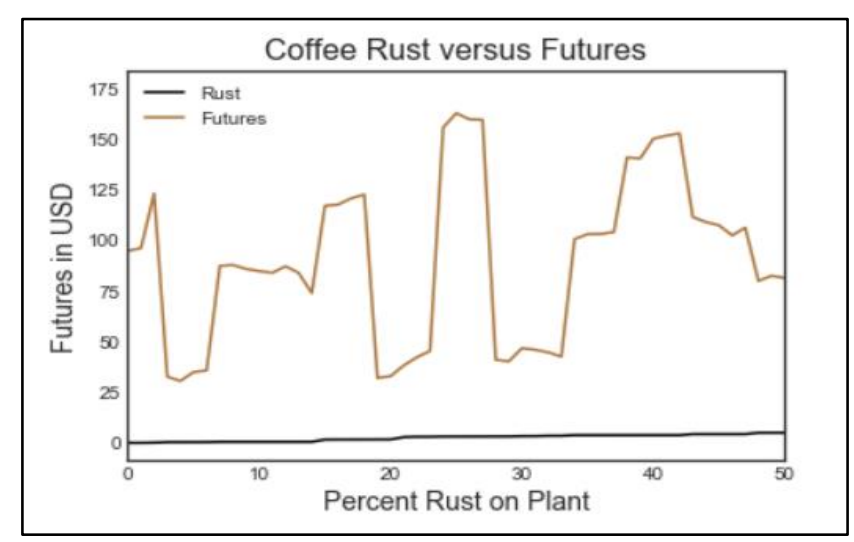

Figure 12. Line Plot of Coffee Rust versus Futures.

In order to accept or fail to accept the original hypothesis, a heat map visualization is needed. Heat maps are a 2D grid whose color in each square shows the value of a data cell in the CSV file. In a heat map, the larger the correlation between two variables, the darker hue on the color scale. The seaborn library within Python was used to create a heat map (https://seaborn.pydata.org/generated/seaborn.heatma p.html). In a heat map, variables that are positively correlated (greater than 0 ) change in the same direction. Variables that are negatively correlated (less than 0) change in the opposite direction. The larger the number on the heat map scale, the greater the correlation between variables.

\section{DISCUSSION}

A discussion on how the relationship between Rain, Temperature, Rust, Production, and Futures was quantified will now be discussed. Since none of the line plots definitively showed a relationship between these

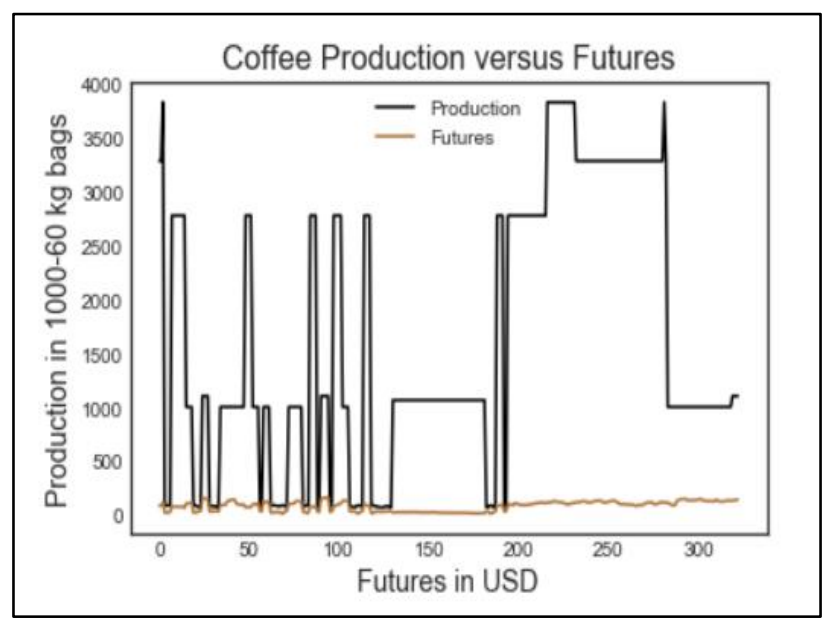

Figure 11. Line Plot of Coffee Production versus Futures.

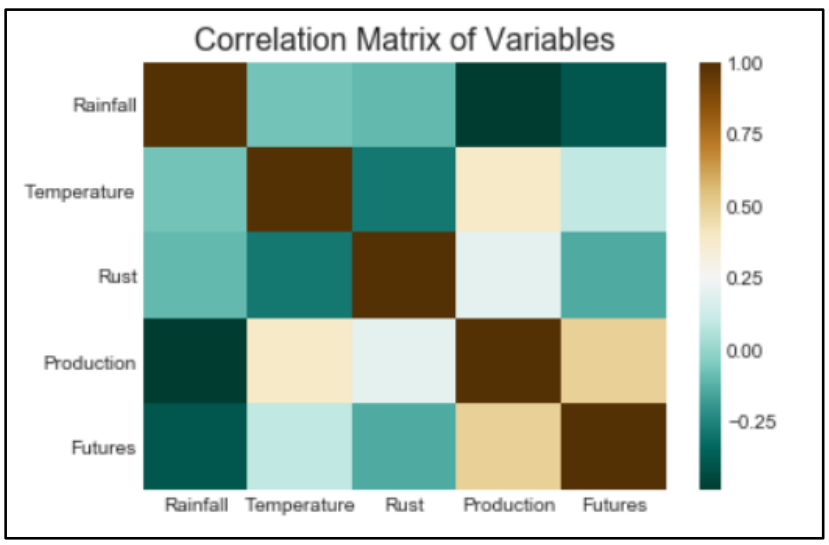

Figure 13. Heat Map of Variables.

variables, a heat map visualization with a diverging color palette ("BrBG") as described in the Seaborn documentation

(https://seaborn.pydata.org/generated/seaborn.heatma p.html) and as shown in Figure 13.

From heat map, the following observations can be made:

- Rain, Temperature, Production, Rust and Futures are quantitatively related to each other.

- Rain and Temperature are not correlated to each other (correlation $=0$ ).

- Rain is not correlated to Rust (correlation $=0$ ).

- Temperature is negatively correlated to Rust (-0.25) so if Temperature increases, Rust decreases.

- Rain is negatively correlated to Production (-0.5) so if Rain increases, Production decreases.

- Production is positively correlated to Futures (0.3) so if Production increases, Futures increase.

- Rust is positively correlated to Production (0.25) so if Rust increases, Production increases. 
- Rust is negatively correlated to futures (-0.1) so if Rust increases, Futures decrease.

From these observations, the following conclusions can be made about our hypotheses.

- Rain, Temperature, Production, Rust and Futures are correlated to each other. $\rightarrow$ Accept

- More Rain increases Rust. $\rightarrow$ Fail to accept

- Higher Temperatures increase Rust. $\rightarrow$ Fail to accept

- More Rust decreases Production. $\rightarrow$ Fail to accept

- Less Production increases Futures. $\rightarrow$ Fail to accept

- More Rust decreases Futures. $\rightarrow$ Accept

Hypothesis 2 (More Rain increases Rust) cannot be accepted since it has a correlation of 0 from the heat map above. This hypothesis contradicts the available literature. It is unclear from the synthesized data why this is the case.

One of the biggest surprises from the heat map in Figure 13 is hypothesis 3 . Recall from the observations that Temperature is negatively correlated to rust $(-0.25)$, meaning that if Temperature increases, Production decreases. This is unexpected since prior research has anecdotally stated that higher Temperatures increase the amount of rust (Jaramillo). Recall from the summary statistics above that the range of Temperatures in our data is $23.47-27.16^{\circ}$ C. Since coffee rust thrives in temperatures from $10-30^{\circ} \mathrm{C}$ and our data falls within this range, it is surprising that increased temperatures do not necessarily increase rust. The hypothesis that increased Temperature increases coffee Rust cannot be accepted.

Another surprising hypothesis that contradicts existing literature is that More Rust decreases Productions. It is unclear from the data synthesized why this is the case.

In addition to the heat map and plots shown in Figures 8-13, the slope and normalized root mean square error (NRMSE) was calculated for Rainfall, Temperature, Production and Futures with respect to Rust.

Table 4. Slope and NRMSE for Temperature, Rainfall, Production and Futures.

\begin{tabular}{lll}
\hline Variable & Slope & NRMSE \\
\hline Temperature & -0.006 & 12.184 \\
Rainfall & -0.380 & 0.139 \\
Production & 10.02 & 0.012 \\
Futures & -0.071 & 0.309 \\
\hline
\end{tabular}

The values shown in Table 4 provide a more granular quantitative framework than the prior visualizations.
The highly positive slope of 10.02 and fairly small NRMSE of 0.012 between Rust and Production indicates the strongest correlation with Rust of all the variables and a small predictive error.

\section{CONCLUSION AND RECOMMENDATIONS}

Only hypothesis 1 and 6 are accepted with the data and subsequent visualizations. Rain, Temperature, Production, Rust and Futures are correlated to each other as shown by the heat map. Furthermore, the methodology above describes that more Rust on the coffee plants decreases the Futures.

Various types of data visualizations provide a quantitative framework for describing the relationship between Temperature, Rainfall, Production, coffee Rust and Futures for Brasil, Colombia and New Caledonia. Since these three countries represent about $40 \%$ of all coffee arábica produced worldwide, similar conclusions can be drawn about the relationships of these variables in other coffee growing regions. Being able to quantify with certain granularity the relationship between Temperature, Rainfall, Rust, Production quantities and Futures prices is an important contribution to practitioners and researchers in the agricultural and financial sectors. The research is a crucial first step in understanding production losses that affect the livelihood of millions of people worldwide.

\section{REFERENCES}

Alves, M. (2012). Cafeicultura De Precisão Na Proteção de Plantas: Monitoramento de Pragas E Doenças. Expocafé 2012 - slide 28. Retrieved October 17, 2017 from https://pt.slideshare.net/cafeicultura/expocafemarcelo

Avelino, J., Zelaya, H., Merlo, A., Pineda, Ordoñez, A. M. \& Savary, S. (2006). The intensity of a coffee rust epidemic is dependent on production situations. Ecological Modeling, 197, 431-447.

Avelino, J., Cristancho, M., \& Georgiou, S. (2015). The coffee rust crisis in Colombia and Central America (2008-2013): impacts, plausible causes and proposed solutions. Food Security, 7, 303.

Beretta, L., \& Santaniello, A. (2016). Nearest neighbor imputation algorithms: a critical evaluation. BMC Medical Information Decision Making, Supplemental 3,74.

Cintra, M., Meira, C.A.A., Monard, M.C., Camargo, H.A. \& Rodrigues, L.H.A. (2011). The Use of Fuzzy 
Decision Trees for Coffee Rust Warning in Brazilian Crops. 11th International Conference on Intelligent Systems Design and Applications. doi:10.1109/ISDA.2011.6121847.

Coffee C Futures (2017). Intercontinental Exchange. $\begin{array}{llll}\text { Retrieved } & 27 & \text { November } & 2017 .\end{array}$ https://www.theice.com/products/15/Coffee-CFutures.

Coffee production in Colombia (2018). Retrieved 28 November 2018. https://en.wikipedia.org/wiki/Coffee_production_ in_Colombia.

Coffee production in Papua New Guinea (2018). Retrieved $27 \quad$ November 2018. https://en.wikipedia.org/wiki/Coffee_production_ in_Papua_New_Guinea.

Coffee: World Markets and Trade. United States Department of Agriculture - Foreign Agricultural Service. Retrieved 8 December 2017.

Color-Hex Color Palettes. Retrieved 21 November 2017. http://www.color-hex.com/color-palette/50402.

Colombian Coffee Insider (2013). Coffee is a Driving Force of the Economy and a Guarantee of Social Stability and Peace. Retrieved 20 November 2018.

Colombian Connection Coffee. Retrieved 5 December 2017.

http://colombianconnection.com.au/coffee/.

Commodity Futures Price Quotes for Coffee. Retrieved 11 September 2017. http://data.tradingcharts.com/futures/quotes/kc. html.

Corrales, D., Ledezma, A., Peña, A., Hoyos, J., Figueroa, A. \& Corrales, J. (2014). A new dataset for coffee rust detection in Colombian crops base on classifiers. $\begin{array}{lll}\text { Revista } & \text { S\&T, 12(29), 9-23. }\end{array}$ https://www.icesi.edu.co/revistas/index.php/sist emas_telematica/article/viewFile/1802/2333

Custudio, A.A. (2011). Comparison and validation of diagrammatic scales for brown eye spots in coffee tree leaves. Ciência e Agrotecnologia 35(6), 10671076.

Cunha, R.L; Mendes, A.N.G.; Chalfoun, S.M. (2004). Controle químico da ferrugem do cafeeiro (Coffea arabica L.) e seus efeitos na produção e preservação de enfolhamento. Ciência e Agrotecnologia, 28(5), 990-996.

Economics of coffee. Retrieved 30 October 2018. https://en.wikipedia.org/wiki/Economics_of_coff ee.

Escobar, K. Coffee Rust is killing Latin American Plants." Retrieved $18 \quad$ October 2017. http://www.dbknews.com/2016/10/28/umdresearch-grant-coffee-rust-fungus/

Hemileia Vastatrix. Retrieved 22 October 2017. https://en.wikipedia.org/wiki/Hemileia_vastatrix. ICO (2016). World Coffee Production. International Coffee Organization. Retrieved 30 October 2018. http://www. ico.org/prices/po-production.pdf..

Japiassú, L. B, A. W.R. Garcia, A.E. Miguel, M.S. A. Mendonça, C.H.S. Carvalho, \& R.A. Ferreira. (2017). Influencia da Carga Pendente, Do Espaçamento e de Fatores Climáticos no Desenvolvimento da Ferrugem do Cafeeiro. Estação de Avisos Fitossanitários Do Mapa/Fundação Procafé. Retrieved $\quad 10 \quad$ October 2017. http://www.sapc.embrapa.br/arquivos/consorcio /spcb_anais/simposio4/p292.pdf.

Jaramillo, J., Muchugu E., Vega, F.E., Davis, A., Borgemeister C., \& Chabi-Olaye A. (2011). Some Like It Hot: The Influence and Implications of Climate Change on Coffee Berry Borer (Hypothenemus hampei) and Coffee Production in East Africa. PLoS ONE 6(9), e24528.

Lamouroux, N., Pellegrin, F., Nandris, D. \& Kohler, F. (1995). The Coffea arabica Fungal Pathosystem in New Caledonia: Interactions at Two Different Spatial Scales. Journal of Phytopathology 143, 403-413.

Lopes, P.R., Ferraz, J.M.G, Theodoro, V.C.A, \& Lopes, L.M. (2012). Evolution of coffee rust (Hemileia vastatrix) and brown eye spot (Cercospora coffeicola) in conventional, organic-mineral and organic coffee agroecosystem. Revista Brasiliera De Agroecologia, 7(1), 160-168.

Luaces, 0. (2011). "Using nondeterministic learners to alert on coffee rust disease." Expert Systems Applications, 38,14276-14283.

McCook, S. and Vandermeer, J. (2015). The big rust and the Red Queen: long-term perspectives on coffee rust research. Phytopathology, 105, 1164-1173.

Montage, D. (2017). Algorithmic Trading of Futures via Machine Learning. Stanford University CS229 Course material. Retrieved 11 September 2017. http://cs229.stanford.edu/proj2014/David\%20M ontague,\%20Algorithmic\%20Trading\%20of\%20F utures\%20via\%20Machine\%20Learning.pdf. 
Paulo, E.M., Montes, S.M.N.M., \& Fischer, I.H. (2013). Progresso temporal da ferrugem alaranjada em cultivares de cafeeiro no Oeste de São Paulo. Arquivos do Instituto Biológico, 80(1), 59-64. doi: 10.1590/S1808-16572013000100009.

Ruiz-Cárdenas, R. \& Baker, P. (2010). Life table of Hypothenemus hampei in relation to coffee berry phenology under Columbian field conditions. Ciência e Agrotecnologia, 67(6), 658-668. $\begin{array}{llll}\text { Retrieved } & 1 & \text { October } & 2017 .\end{array}$ http://www.scielo.br/scielo.php?script=sci_arttex t\&pid=S0103-90162010000600007.
Souza, R.M (2008), Plant-Parasitic Nematodes of Coffee, Springer Science \& Business Media B.V.

World Bank Climate Change Knowledge Portal. Retrieved November

1 , 2017. http://sdwebx.worldbank.org/climateportal/inde x.cfm?page $=$ country_historical_climate\&ThisCCod $\mathrm{e}=$ PNG.

Yap, J. (2017). Stat 531 Midterm Project. Retrieved November 1, 2017 https://ionides.github.io/531w16/midterm_proje ct/project10/midtermproject.html

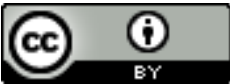

